\title{
A Escolha da Estrutura de Capital sob Fraca Garantia Legal: O Caso do Brasil ${ }^{*}$
}

\author{
Ricardo D. Brito ${ }^{* *}$ \\ Mônica R. Lima ${ }^{* * *}$
}

Sumário: 1. Introdução; 2. Algumas previsões sobre a estrutura de capital; 3. Diferenças entre variáveis contábeis e de mercado; 4. Evidências empíricas; 5. Dados; 6. Metodologia de análise; 7. Resultados; 8. Considerações finais.

Palavras-chave: estrutura de capital; arcabouço legal ineficaz; governança corporativa; origem do controlador.

Códigos JEL: G32; G34.

Este artigo mostra que as empresas de controle privado nacional se endividam mais que as de controle público ou estrangeiro, e o fazem pelo uso intensivo de dívida de curto prazo. A relação positiva entre ativos tangíveis e alavancagem de longo prazo confirma a previsão de trade-off. Divergindo das evidências brasileiras anteriores, o crescimento apresenta relação positiva com o endividamento, o que, conjuntamente com a relação negativa da rentabilidade, favorece a teoria de pecking order contra a de trade-off. Finalmente, e mais interessante, a maior sensibilidade do endividamento das empresas privadas nacionais aos fatores analisados parece indicar que os direitos do investidor externo à firma são menos resguardados pelo controlador privado nacional.

This paper shows that the domestic controlled companies are more leveraged than the state controlled or than the foreign controlled ones, and that the formers make intensive use of short-term debt. The positive relation between tangible assets and long-term debt is consistent with the trade-off model's prediction. Different from previous evidences, investment opportunities are positively related to leverage, which combines with an inverse relation to profitability to favor the pecking order model against the trade-off model.

\footnotetext{
*Artigo recebido em set. 2003 e aprovado em ago. 2004. Agradecemos a Eurilton Araújo (Ibmec São Paulo), Jose F. Barbachan (Faculdades Ibmec/RJ), Sérgio G. Lazzarini (Ibmec São Paulo), Ricardo P. Leal (COPPEAD/UFRJ), Julio Cesar Silva (Faculdades Ibmec/RJ) e a dois pareceristas anônimos pelas valiosas sugestões e comentários. Todos as imprecisões remanescentes são de nossa exclusiva responsabilidade.

** Ibmec São Paulo. E-mail: ricardodob@ibmec.br

${ }^{* * *}$ BB DTVM e Faculdades Ibmec/RJ. E-mail: mlima@bb.com.br
} 
Finally, and more interestingly, the higher sensitivity of domestic controlled firms' leverage to the analyzed factors seems to indicate that outsiders' rights are less protected by domestic insiders.

\section{Introdução}

Desde a proposição da irrelevância de Modigliani e Miller (1958), explica-se a escolha da estrutura de capital a partir da violação de suas hipóteses. Fundamentadas em alguma imperfeição de mercado, as modernas teorias derivam os impactos das decisões de financiamento sobre valor da firma e apontam os determinantes da escolha ótima de estrutura de capital. Por exemplo, na teoria de trade-off (DeAngelo e Masulis (1980), Jensen e Meckling (1976), Stulz (1990)) existem custos e benefícios do endividamento, e as firmas escolhem sua alavancagem pela ponderação entre custos e benefícios de uma unidade adicional de dívida. Já na teoria de pecking-order (Myers (1984)) os custos de emissão de novos títulos sobrepujam seus benefícios, e as firmas priorizam o financiamento por lucros retidos, seguido de dívida e ações como último recurso.

Quais imperfeições têm importância prática na escolha ótima de estrutura de capital é uma questão para análise empírica, que pode verificar a significância dos efeitos implicados pelas várias teorias, bem como ajuizar aqueles pontos onde estas divergem. Ao longo dos últimos anos, trabalhos como os de Titman e Wessels (1988) e Barclay e Smith Jr. (1995) para os EUA, ou Rajan e Zingales (1995) para os países do G7, entre outros, buscam identificar quais são os fatores determinantes da escolha da estrutura de capital das empresas.

Para o Brasil existem alguns trabalhos nesta linha. Gomes e Leal (2001), por exemplo, efetuam um estudo seccional do endividamento médio do período entre 1995 e 1997 para os fatores tamanho, tangibilidade, crescimento, risco e subsetor industrial. Encontram relação positiva entre o nível de endividamento e os fatores tangibilidade e risco; relação inversa para os fatores rentabilidade, crescimento e tamanho; e resultados não-significativos para classificação da indústria. Já Perobelli e Famá (2002) utilizam análise fatorial para examinar os efeitos do tamanho, tangibilidade, crescimento, risco, margem, lucratividade e singularidade sobre o endividamento do período de 1995 a 2000. Embora os últimos não consigam inferir os determinantes do endividamento de longo prazo, são capazes de concluir que o endividamento de curto prazo está negativamente relacionado aos fatores tamanho, crescimento e lucratividade. Com o objetivo de analisar a escolha da estrutura de capital pelas subsidiárias estrangeiras, Novaes e Werlang (2002) utilizam o Brasil entre 1985 e 1994 como exemplo de país com alto risco político.

RBE Rio de Janeiro 59(2):177-208 ABR/JUN 2005 
Mostram que as empresas estrangeiras se endividam mais que as equivalentes nacionais como defesa contra a possibilidade de expropriação.

Este artigo estende as análises anteriores, estudando a importância da origem dos controladores - se privado nacional, público nacional ou com significativa participação estrangeira - na determinação da estrutura de capital das empresas brasileiras entre 1995 e 2001. O objetivo é verificar se, num ambiente de fraca garantia legal, a origem do controlador oferece um colateral fiduciário ao investidor externo à firma.

La Porta et alii (1998) caracterizam o Brasil como um país onde o investidor externo à firma é pouco protegido pelo arcabouço jurídico contra expropriação pelo controlador. Para todos os indicadores referentes à eficiência da legislação e de sua execução pelo poder judiciário para a proteção dos direitos dos investidores externos à firma, o Brasil se encontra abaixo da média internacional numa amostra de 49 países (ver La Porta et alii (1998), tabela 5, pág. 1142). Neste mercado mais imperfeito, esperam-se maiores problemas de agência, fontes externas de recursos mais caras e maior importância da governança individual. A hipótese proposta é que uma participação estrangeira significativa sinaliza uma governança melhor, seja porque boa governança é condição necessária para atrair o sócio estrangeiro, seja porque à reputação do sócio estrangeiro importa a boa governança. Isto posto, as empresas de controle privado nacional, com governança pior e maiores custos esperados de agência, não só têm maiores custos de capital de terceiros, como maiores custos relativos para aquelas formas onde o investidor fica mais sujeito à expropriação. Este maior custo de capital de terceiros justifica uma pecking order relativamente mais forte para as firmas de controle privado nacional que para aquelas com significativa participação estrangeira. Ou seja, negócios de controle privado nacional devem ser mais radicais na prioridade ao financiamento por recursos internos, seguido por dívida de curto prazo, longo prazo e finalmente pela emissão de ações para novos sócios (external equity).

Para verificação da previsão de menor utilização do financiamento externo à firma, faz-se necessário analisar o comportamento da soma da dívida total com o valor das ações em poder dos minoritários, última informação que não se encontra facilmente disponível. ${ }^{1}$ Uma implicação testável da previsão de pecking order mais forte para firmas de controle privado nacional é a maior sensibilidade de suas dívidas a fatores como tangibilidade, rentabilidade, crescimento e risco. Por exemplo, espera-se uma relação mais negativa entre endividamento total e ren-

\footnotetext{
${ }^{1}$ Note que a menor alavancagem total não é uma previsão trivial da pecking order mais forte, dado que os custos da dívida tendem a ser menos sensíveis aos riscos de agência que os custos de emissão de novas ações.
}

RBE Rio de Janeiro 59(2):177-208 ABR/JUN 2005 
tabilidade das empresas de controle privado nacional. Outra previsão de exame direto é a de menor duração da dívida das firmas de controle privado nacional. Aqui, estudam-se as dívidas de curto prazo, longo prazo e total como proporção do ativo em termos contábeis ou do ativo em valor de mercado, analisando suas diferenças de sensibilidade ao tipo de controle, à tangibilidade, ao crescimento, à rentabilidade e ao risco.

Note-se que a boa governança indicada pela participação estrangeira difere em essência da sinalização de boa governança pela admissão no mercado americano, estudada por Reese e Weisbach (2002). Embora possam estar relacionadas na prática, na última as firmas efetivamente se submetem à mais rigorosa justiça dos EUA, enquanto que na primeira a reputação de boa governança do sócio estrangeiro oferece uma garantia fiduciária. A eficácia da admissão no mercado americano sobre a melhoria da governança das firmas brasileiras está estudada em Srour (2002). No presente trabalho não se examina a causalidade entre acesso a financiamento internacional e boa governança, mas se o mercado percebe como positiva a relação entre participação estrangeira e boa governança e qual a implicação desta para a estrutura de capital ótima.

Como proposto em Fama e French (2002), a metodologia utilizada segue Fama e Macbeth (1973) ao invés de regressões seccionais ou de painel. Quando as regressões seccionais são empregadas, o problema de correlação dos resíduos entre as empresas é ignorado. Os artigos que usam regressões de painel ignoram, além do problema de correlação seccional, o problema de viés dos erros-padrão dos coeficientes estimados devido à correlação ao longo dos anos das medidas seccionais. Neste artigo, efetuam-se ajustes para correlação seccional e autocorrelação, quase sempre ignorados em estudos anteriores.

Considerando simultaneamente tangibilidade, crescimento, rentabilidade e risco, indica-se que a origem do controlador é uma variável relevante. Mostra-se que as empresas de controle privado nacional se endividam mais que as de controle público nacional ou de controle estrangeiro, e que isso é conseguido pelo uso intensivo de mais dívida de curto prazo. A relação positiva entre o fator tangibilidade e endividamento total ou de longo prazo confirma o previsto pela teoria de trade-off. Por outro lado, divergindo de Gomes e Leal (2001) e Perobelli e Famá (2002), o crescimento apresenta relação positiva com o endividamento. Esta última evidência, conjuntamente com a relação negativa da rentabilidade, favorece a teoria de pecking order contra a teoria de trade-off. Ainda, a volatilidade se mostra negativamente relacionada à dívida de longo prazo, como esperado por trade-off e pecking order.

RBE Rio de Janeiro 59(2):177-208 ABR/JUN 2005 
Finalmente, a contribuição mais original é a maior sensibilidade do endividamento das empresas privadas nacionais aos fatores analisados, indicando maiores custos de agência. A interpretação é que os direitos do investidor externo são menos resguardados pelo controlador privado nacional, o que majora os custos de agência, e conseqüentemente os custos dos recursos externos, fortalecendo a hierarquia da pecking order.

A fundamentação teórica do trabalho é apresentada nas próximas três seções: algumas previsões sobre a estrutura de capital, diferenças entre valores contábeis e valores de mercado e evidências empíricas. Os dados estão descritos na seção 5 . A seção 6 é dedicada à metodologia da análise empírica. Na seção 7 são analisados os resultados. Finalmente, a seção 8 faz as considerações finais.

\section{Algumas Previsões sobre a Estrutura de Capital}

A proposição da irrelevância da alavancagem para o valor da firma num mercado perfeito e sem impostos, por Modigliani e Miller (1958), estabelece a base da moderna teoria de estrutura de capital ao definir uma heurística passível de adaptação a outras condições. Por exemplo, com a possibilidade de dedução tributária dos serviços da dívida, Modigliani e Miller (1963) demonstram que o valor da empresa depende linearmente do seu nível de endividamento, indicando que as empresas deveriam apresentar o maior grau de alavancagem possível.

Como as firmas efetivamente combinam dívida e recursos próprios em sua estrutura de capital, desenvolveu-se a teoria de trade-off do endividamento, onde a alavancagem ótima é o resultado da ponderação entre os seus custos e benefícios. Em Miller (1977), o endividamento agregado ótimo é aquele que iguala a alíquota de imposto sobre o rendimento dos títulos do credor marginal com o imposto sobre o retorno do acionista, mas sem ganho de valor da firma pela sua decisão de financiamento.

DeAngelo e Masulis (1980) mostram que a irrelevância da alavancagem sobre o valor da firma de Miller (1977) é sensível a adaptações realistas como a inclusão de custos de falência, monitoramento e outros custos individuais decorrentes do financiamento por dívida. Porque o custo de insolvência é menor para empresas com maior valor de liquidação, negócios com maior proporção de ativos tangíveis tendem a utilizar relativamente mais dívida. Da mesma forma, firmas mais lucrativas ou menos voláteis têm menor probabilidade de inadimplência e devem ser mais endividadas, pois possuem menores custos esperados de falência. 
Jensen e Meckling (1976) introduzem custos de agência à teoria de trade-off ao observarem os conflitos de interesses inerentes à divisão da firma em obrigações e direitos assimétricos entre acionistas, gerente e credores. O conflito entre acionistas e gerente surge quando este não detem a totalidade das ações da empresa. Como o gerente não captura todo o crescimento dos lucros causado pelo seu esforço adicional, mas arca com a integridade deste, seu nível de empenho pode diferir do ótimo. Já o conflito entre acionistas e credores emerge em situações de insolvência. A responsabilidade limitada incentiva os acionistas de firmas insolventes mas com fluxos de caixa livres a investirem em projetos arriscados, mesmo que com valor presente líquido esperado negativo, uma vez que desfrutarão dos ganhos do sucesso e repassarão aos credores os custos do fracasso. Ou ainda, a prioridade da dívida desincentiva os acionistas de empresas insolventes e sem fluxos de caixa livres a investirem recursos em novos projetos, mesmo que com valor presente líquido esperado positivo, visto que os benefícios pertencerão aos credores. Essas possibilidades de investimento exagerado (overinvestment) ou investimento insuficiente (underinvestment) são antecipadas pelo mercado que as incorpora à taxa cobrada pelo empréstimo e reduz o valor da empresa. A este custo de agência dá-se o nome de efeito substituição do ativo (asset substitution effect).

Dado que a divisão assimétrica da firma cria oportunidades de aumento do valor de um grupo às custas de outro, muitas vezes com redução do valor total do negócio, utiliza-se a estrutura de capital para minimizar tais conflitos. Entre seus benefícios, o endividamento contribui para que o gerente se empenhe em maximizar o valor da empresa, na medida em que aumenta sua participação relativa na mesma e em seus lucros, além de reduzir os fluxos de caixa livres passíveis de destinação não-produtiva. Pelo lado dos custos, a alavancagem causa o efeito substituição do ativo. Da compensação entre benefícios e custos da dívida resulta que empresas mais lucrativas devem apresentar maior nível de endividamento e aquelas sujeitas a maior efeito substituição do ativo devem apresentar menor nível de endividamento. Em geral, empresas com maiores oportunidades de investimento correm maior risco de investimento insuficiente e devem apresentar menores níveis de endividamento. Por outro lado, quanto mais restritas as oportunidades de investimento, maior o risco de investimento exagerado e maior o nível de endividamento indicado.

Como alternativa à escolha marginalista da teoria de trade-off, o modelo de pecking order de Myers (1984) descreve uma situação onde, sob informação assimétrica, os custos de financiamento por terceiros extrapolam qualquer benefício. A assimetria de informação entre gerentes e agentes externos causa a redução dos preços dos títulos arriscados da empresa que tenta emiti-los porque o mercado interpreta esta opção de financiamento como evidência de superavaliação. Uma 
vez que essa queda de preço dos títulos reduz a riqueza dos sócios atuais, um projeto de valor presente líquido positivo que necessite de financiamento externo pode ser rejeitado. Como os benefícios do endividamento são de segunda ordem, não há grau de alavancagem ótimo e a dívida da firma passa a ser definida pela sua disponibilidade de fluxos de caixa. Para minimizar distorções, estabelece-se uma hierarquia das formas de financiamento que minimiza o custo da informação assimétrica, onde recursos internos são preferíveis a externos e a emissão de dívida é preferível à emissão de ações. Visto que negócios mais rentáveis têm a opção de utilizar recursos internos, o modelo prevê menor alavancagem para empresas mais lucrativas, contrário ao previsto pela teoria de trade-off. Também em discordância com trade-off, pecking order sugere uma relação positiva entre oportunidades de investimento e endividamento, posto que o nível de dívidas é determinado pelas diferenças acumuladas entre investimentos e lucros retidos. ${ }^{2}$ Finalmente, firmas com fluxos de caixa menos arriscados podem se endividar mais, pois são menores as chances de terem que emitir títulos arrriscados ou cancelarem investimentos promissores.

A tabela 1 sumariza a relação esperada entre o nível de endividamento e os fatores determinantes nos modelos de trade-off e pecking order.

Tabela 1

Relação teórica entre o fator e o endividamento

\begin{tabular}{lcc}
\hline Fator & Teoria & Previsão \\
\hline Tangibilidade & Trade-off & positiva \\
Rentabilidade & $\begin{array}{c}\text { Trade-off } \\
\text { Pecking Order }\end{array}$ & $\begin{array}{c}\text { positiva } \\
\text { negativa }\end{array}$ \\
Crescimento & $\begin{array}{c}\text { Trade-off } \\
\text { Pecking Order }\end{array}$ & $\begin{array}{c}\text { negativa } \\
\text { positiva }\end{array}$ \\
Risco & $\begin{array}{c}\text { Trade-off } \\
\text { Pecking Order }\end{array}$ & $\begin{array}{l}\text { negativa } \\
\text { negativa }\end{array}$ \\
\hline
\end{tabular}

\footnotetext{
${ }^{2}$ Esta é a previsão do modelo simples de pecking-order, segundo Fama e French (2002). Na sua versão complexa, a consideração de custos de financiamentos futuros pode justificar um baixo endividamento atual.
} 
Além de previsões quanto ao nível de endividamento, as teorias de trade-off e pecking order também são capazes de sugerir a duração ótima da dívida, como detalhado em Barclay e Smith Jr. (1995). Da teoria de trade-off, negócios com maiores oportunidades de crescimento devem ter mais dívida de curto prazo para evitar problemas de investimento insuficiente. Ou, como diretores de empresas com significativa participação pública têm menor poder discricionário sobre a política de investimentos, são menores os efeitos adversos da dívida de longo prazo e é indicado o seu uso mais intensivo (Smith Jr. (1986), segundo Barclay e Smith Jr. (1995)). Adaptando de Barclay e Smith Jr. (1995) para o Brasil, resulta que firmas com sócios estrangeiros devem ter dívidas emitidas no exterior, onde os prazos são mais longos e, portanto, devem apresentar uma duração maior. Ainda, firmas com maiores problemas de informação assimétrica tendem a privilegiar financiamentos de curto prazo devido aos maiores custos de informação associados a empréstimos de longo prazo (Flannery (1986), segundo Barclay e Smith Jr. (1995)).

Surgida a partir de La Porta et alii (1998), uma literatura recente, que relaciona o desenvolvimento das instituições de financiamento à eficiência do arcabouço jurídico, também pode ser relacionada às teorias de trade-off e pecking order. Como evidenciado por La Porta et alii (1997), em países onde o investidor externo à firma é pouco protegido pelas instituições do direito contra expropriação pelo controlador, devem ser mais caras as fontes externas de financiamento e menos intenso o seu uso. Também parece intuitivo que a boa governança corporativa seja mais relevante num ambiente de menor proteção legal dos direitos dos investidores, e que os maiores custos esperados dos financiadores impliquem uma maior importância de fatores como colaterais tangíveis, risco e informação para aqueles agentes de pior governança. Mais, espera-se neste cenário que negócios com pior governança utilizem menos financiamento externo e o façam segundo uma pecking order que priorize as formas menos sujeitas à expropriação.

Havendo La Porta et alii (1998) caracterizado o Brasil como um país onde o investidor externo à firma é pouco protegido para padrões internacionais, constitui-se num ambiente ideal para inferir sobre a importância da boa governança corporativa na escolha da estrutura de capital. Uma participação estrangeira significativa indica uma governança melhor porque sinaliza que a companhia tem um padrão internacional de respeito aos direitos de propriedade. Por outro lado, as empresas de controle privado nacional, com pior governança e maiores custos esperados de concordata e falência, não só têm maiores custos de capital de terceiros, como devem ter maiores custos relativos para aquelas formas de financiamento externo 
onde o credor fica mais exposto. Espera-se neste cenário que negócios de controle privado nacional utilizem menos financiamento externo e o façam com mais dívida de curto prazo que aqueles com significativa participação estrangeira.

\section{Diferenças entre Variáveis Contábeis e de Mercado}

Como as previsões descritas acima são para o endividamento relativo, medese o endividamento da empresa como proporção do ativo em valor contábil ou do ativo em valor de mercado. Segundo Fama e French (2002), as relações entre os fatores e as duas medidas de alavancagem definidas na frase anterior podem diferir, sendo que em alguns casos não é possível concluir sobre a relação entre o endividamento de mercado e os fatores em termos contábeis.

Os custos de agência do modelo de trade-off recomendam uma relação positiva entre lucros e dívida. Assim, dividindo os lucros e a dívida pelo valor contábil dos ativos mantém-se a relação positiva entre rentabilidade e endividamento contábil. Como o aumento dos lucros contribui para o aumento do valor de mercado dos ativos da empresa, não há conclusões a respeito da alavancagem como proporção do valor de mercado dos ativos. Na pecking order, tem-se que empresas com alta rentabilidade apresentam menos endividamento como proporção do valor contábil dos ativos. Dado que o valor de mercado aumenta com o aumento da rentabilidade, a relação negativa também é esperada para a alavancagem de mercado.

Com relação ao fator crescimento, o modelo de trade-off indica uma relação negativa entre endividamento contábil e crescimento. Considerando que o valor de mercado da empresa cresce ao menos na mesma proporção dos novos investimentos, a relação entre oportunidades de crescimento e endividamento de mercado também é negativa. Pela teoria de pecking order, o nível de dívidas é determinado pelas diferenças acumuladas entre investimentos e lucros retidos. Assim sendo, calculando-se o fator como proporção do valor contábil dos ativos, e assumindo que os investimentos e lucros são persistentes, a relação entre investimentos e endividamento contábil é positiva. Já, considerando que o valor de mercado da empresa cresce ao menos na mesma proporção dos novos investimentos, não há previsão para a alavancagem de mercado.

\section{Evidências Empíricas}

A tabela 2 apresenta um resumo de alguns trabalhos empíricos, destacando os fatores determinantes da estrutura de capital, país, metodologia utilizada, variáveis dependentes, relações esperadas pelos autores e resultados.

RBE Rio de Janeiro 59(2):177-208 ABR/JUN 2005 
Tabela 2

Resumo das evidências empíricas

\begin{tabular}{|c|c|c|c|c|c|c|c|}
\hline Autores & País & Método & Var. Dependente & Fatores Testados & $\begin{array}{c}\text { Resultados } \\
\text { Esperados }\end{array}$ & $\frac{\text { Resul }}{\text { Contábil }}$ & Idos \\
\hline & & Parte A. & Evidências Emp & ricas Internacionais & & & \\
\hline & & & & tangibilidade & + & ns & ns \\
\hline & & & & crescimento & - & ns & ns \\
\hline & & & $\mathrm{CP}, \mathrm{LP}$ e & tamanho & + & - & - \\
\hline Titman, S & EUA & Análise Fatorial & Dívida & risco & - & ns & ns \\
\hline Wessels, R & & Cross-Section & Conversível & rentabilidade & - & ns & - \\
\hline & & & por Valor & singularidade & - & - & - \\
\hline & & & Contábil & esc. impostos & - & ns & ns \\
\hline & & & e de Mercado & não dívida & & & \\
\hline & & & & $\begin{array}{l}\text { classificação } \\
\text { da indústria } \\
(1)\end{array}$ & & ns & $-(2)$ \\
\hline & & & $\mathrm{CP}+\mathrm{LP}$ & tangibilidade & + & + & + \\
\hline Rajan, R & G7 & Cross-Section & por Valor & crescimento & - & - & - \\
\hline Zingales, $\mathrm{L}^{(3)}$ & & & Contábil & tamanho & + & + & + \\
\hline & & & e de Mercado & rentabilidade & - & - & - \\
\hline & & & & tangilibidade & + & $-(4)$ & na \\
\hline & & & $\mathrm{CP}, \mathrm{LP}$ & crescimento & + & + & na \\
\hline Jorge, S & Portugal & Painel & $(\mathrm{CP}+\mathrm{LP})$ & tamanho & + & ns & na \\
\hline Armada, M & & & por Valor & risco & - & ns & na \\
\hline & & & Contábil e & rentabilidade & - & $+/-^{(5)}$ & na \\
\hline & & & $\begin{array}{c}(\mathrm{CP}+\mathrm{LP}) \\
\text { por } \mathrm{PL}\end{array}$ & $\begin{array}{l}\text { esc. impostos } \\
\text { não dívida }\end{array}$ & $+/-$ & ns & na \\
\hline & & & & setor de atividade ${ }^{(1)}$ & & ns & na \\
\hline & & & & controle acionário $^{(1)}$ & & ns & na \\
\hline & & Parte B. & Evidências Emp & íricas para o Brasil & & & \\
\hline & & & & tangibilidade & + & ns & + \\
\hline & & & $\mathrm{CP}, \mathrm{LP}$ & crescimento & - & ns & - \\
\hline Gomes, G & - & Cross-Section & $\mathrm{CP}+\mathrm{LP}$ & tamanho & + & ns & - \\
\hline Leal, $\mathrm{R}$ & & & por Valor & risco & - & + & + \\
\hline & & & Contábil & rentabilidade & - & - & - \\
\hline & & & e de Mercado & $\begin{array}{l}\text { classificação } \\
\text { da indústria }\end{array}$ & & ns & ns \\
\hline & & & & tangibilidade & + & ns & na \\
\hline & & & & crescimento & - & - & na \\
\hline Perobelli, $\mathrm{F}^{(6)}$ & - & Análise Fatorial & CP e LP & tamanho & + & - & na \\
\hline Fama, R & & Cross-Section & por Valor & risco & - & ns & na \\
\hline & & & Contábil & margem $^{(7)}$ & - & ns & na \\
\hline & & & & lucratividade ${ }^{(8)}$ & - & - & na \\
\hline & & & & singularidade & - & ns & na \\
\hline
\end{tabular}

$\mathrm{CP}+\mathrm{LP}=$ Endividamento Geral; $\mathrm{PL}=$ Patrimônio Líquido; $\mathrm{ns}=$ não significativo; na= não analisado; (1) determinar se são relevantes ou irrelevantes para a estrutura de capital; (2) somente para endividamento de longo prazo a valor de mercado; ${ }^{(3)}$ resultados significativos para a maior parte dos fatores de cada país do G7; ${ }^{(4)}$ quando mensurado em termos de Ativos Intangíveis/Ativo Total; ${ }^{(5)}$ dependendo da variável independente utilizada para medir o fator; ${ }^{(6)}$ os resultados referem-se ao endividamento de curto prazo, dado que o endividamento de longo prazo não se mostrou significativo para nenhum dos fatores analisados; (7) margem $=$ resultado operacional/receita líquida; ${ }^{(8)}$ lucratividade $=$ resultado operacional/ativo total

RBE Rio de Janeiro 59(2):177-208 ABR/JUN 2005 
Titman e Wessels (1988) analisam os fatores determinantes da estrutura de capital para o mercado americano para o período de 1974 a 1982 . Como descrito na tabela 2, parte A, encontram que o nível de endividamento das empresas americanas apresenta uma relação negativa com os fatores singularidade ${ }^{3}$ (para o endividamento de curto e longo prazos), rentabilidade (curto e longo prazos) e tamanho (curto prazo). O artigo destaca que empresas menores apuram custos de endividamento inferior ao custo de emissão de ações, especialmente no curto prazo, devendo manter maior nível de endividamento de curto prazo. A evidência empírica encontrada por Titman e Wessels (1988) de que empresas com maior nível de rentabilidade tendem a apresentar menor nível de endividamento mostrase coerente com a teoria de pecking order.

Rajan e Zingales (1995) analisam os fatores determinantes da estrutura de capital para os países do G7 (EUA, Japão, Alemanha, França, Itália, Reino Unido e Canadá) abrangendo o período de 1987 a 1991. O estudo indica que a similaridade do nível de endividamento entre as empresas nos países do G7 foi superior à prevista. Conforme descrito na tabela 2, parte A, os autores encontram relação positiva entre o nível de endividamento e os fatores tangibilidade e tamanho; e negativa para os fatores crescimento e rentabilidade. Estes resultados são coerentes com os de Titman e Wessels (1988), com exceção das evidências para o fator tamanho, para o qual Rajan e Zingales (1995) identificam uma relação positiva com o nível de endividamento. Assim sendo, se por um lado os resultados relativos à tangibilidade, ao crescimento e ao tamanho indicam relação com a teoria de trade-off; por outro, o resultado relativo a rentabilidade é mais aderente à teoria de pecking order, a exemplo do que já havia sido anteriormente identificado para Titman e Wessels (1988).

Jorge e Armada (2001) desenvolvem estudo com o objetivo de identificar os fatores determinantes do nível de endividamento das empresas portuguesas para o período de 1990 a 1995. De forma geral, seus fatores se mostram pouco explicativos. A relação positiva entre o fator crescimento e a alavancagem das empresas portuguesas é oposta à obtida por Rajan e Zingales (1995) e acorda com a previsão de pecking order. O fator rentabilidade, quando medido pelo indicador RAJI/Ativo Total, ${ }^{4}$ resulta numa relação negativa com o endividamento, confirmando a teoria

\footnotetext{
${ }^{3}$ Refere-se a empresas com produtos especializados e/ou únicos.

${ }^{4} \mathrm{RAJI}=$ Resultado líquido + Custos Financeiros de Financiamento + Impostos sobre o Rendimento.
}

RBE Rio de Janeiro 59(2):177-208 ABR/JUN 2005 
de pecking order. Contudo, quando os autores utilizam a razão Resultado Operacional/Ativo Total, obtêm uma relação positiva, o que faz concluir que a conta Resultado Extraordinário, única diferença entre as duas medidas, exerce influência sobre o endividamento das empresas.

Em resumo, as evidências empíricas internacionais indicam que o fator rentabilidade apresenta uma relação negativa com o nível de endividamento confirmando a teoria de pecking order. Quanto aos fatores tangibilidade, crescimento e tamanho os resultados foram contraditórios. Por fim, os fatores setor de atividade, benefícios fiscais que não os gerados pela dívida (non-debt tax shields) e controle acionário não se mostraram significativos, como pode ser observado na tabela 2 , parte A.

Para o Brasil, os resultados obtidos por Gomes e Leal (2001) no período entre 1995 e 1997 estão reportados na tabela 2, parte B. Os autores encontram relação positiva entre a alavancagem e os fatores tangibilidade e risco; relação inversa para os fatores rentabilidade, crescimento e tamanho; e resultados não-significativos para a classificação da indústria. ${ }^{5}$ Segundo Gomes e Leal (2001), os juros elevados praticados no Brasil e a ausência de financiamento de longo prazo podem explicar porque empresas grandes, que têm acesso a outras fontes de financiamento, tais como emissões de ações no exterior, parecem optar por um menor nível de endividamento, enquanto que as empresas menores ficam praticamente restritas às linhas de curto prazo. A relação negativa encontrada para o fator crescimento coincide com a teoria de trade-off, a exemplo do verificado por Rajan e Zingales (1995). A relação negativa entre o endividamento e rentabilidade acorda com a teoria de pecking order, a exemplo do verificado por Titman e Wessels (1988) e Rajan e Zingales (1995).

Perobelli e Famá (2002) também analisam o Brasil no período de 1995 a 2000 e encontram evidências de que a dívida de curto prazo está negativamente relacionada aos fatores crescimento, tamanho e lucratividade das empresas, como pode ser observado na tabela 2, parte B. A análise dos dois primeiros fatores revela que empresas brasileiras de menor porte são mais propensas ao endividamento de curto prazo. Além disso, o estudo destaca que empresas em crescimento tendem a utilizar menos os mecanismos de financiamento de curto prazo que, no Brasil, cobram taxas superiores às linhas de longo prazo. Quanto ao fator rentabilidade, o estudo revela que empresas com alta razão Resultado Operacional Líquido/Ativo Total são menos endividadas no curto prazo que aquelas com baixa razão Resultado Operacional Líquido/Ativo Total, conforme pode ser observado na tabela 2, parte B. Coincidindo com Gomes e Leal (2001), a teoria de trade-off parece explicar a

\footnotetext{
${ }^{5}$ Os autores classificam as empresas em 24 setores.
} 
relação negativa entre a alavancagem e o crescimento, e a teoria de pecking order parece justificar a relação negativa entre o fator rentabilidade e o endividamento.

Além dos trabalhos tabulados acima, outros que abordam características específicas das empresas brasileiras merecem menção. Ao analisar o comportamento das empresas no que se refere à decisão de estrutura de capital, Eid Jr. (1996) conclui que a maioria das empresas brasileiras age oportunisticamente, preferindo a forma de financiamento que momentaneamente pareça mais vantajosa aos controladores. O autor destaca, também, a existência de um grande número de empresas que seguem uma hierarquia de captação predeterminada, dando grande importância à sua sobrevivência, independência e flexibilidade financeira.

Kayo e Famá (1997), analisando o período de 1992 a 1996, encontram evidências de que o uso de dívidas pode exercer efeitos positivos ou negativos sobre o valor das empresas, dependendo da existência de oportunidades de crescimento. Os autores concluem que quando existem boas oportunidades de crescimento, as empresas optam pela predominância de capitais próprios, dado os efeitos negativos da dívida na fase de alto crescimento (agrava os problemas de investimento insuficiente); por outro lado, nas empresas de baixo crescimento, a predominância é de capitais de terceiros, indicando os efeitos positivos da dívida (reduz os problemas de investimento exagerado).

Moreira e Puga (2001), analisando o período de 1995 a 1997, identificam os recursos internos como a principal fonte de financiamento do crescimento das empresas brasileiras, seguido pela emissão de dívida e pelo lançamento de ações. Os autores encontram evidências de maior propensão das empresas nacionais a recorrerem ao mercado acionário e indícios de um maior grau de alavancagem por parte das estrangeiras. Além disso, os resultados indicam que empresas de menor porte são mais dependentes de recursos próprios, provavelmente, devido às barreiras para obtenção de empréstimos. Os autores destacam, ainda, a maior alavancagem das empresas mais intensivas em capital, seja pela maior capacidade de oferecer garantias, seja pelas maiores necessidades de investimento por unidade de produto.

Analisando o ano 2000, Carvalhal Da Silva (2002) encontra evidências de relação entre a estrutura de controle/propriedade e estrutura de capital. O autor conclui que: empresas com direitos de voto concentrados pelos acionistas controladores têm alto nível de alavancagem; empresas com direitos de fluxo de caixa concentrados pelos acionistas controladores têm baixo nível de alavancagem; e em- 
presas com grande separação entre direitos de voto e fluxo de caixa têm alto nível de alavancagem. ${ }^{6}$ Além disso, destaca que empresas controladas pelo governo tendem a ser menos alavancadas que as demais.

Finalmente, Novaes e Werlang (2002) comparam o endividamento de longo prazo das subsidiárias estrangeiras com suas equivalentes brasileiras entre 1985 e 1994 e concluem que as primeiras se endividam relativamente mais sob risco de expropriação elevado. Simultaneamente, mostram que a alavancagem tem relação positiva com a tangibilidade e relação inversa com a rentabilidade, de acordo com Gomes e Leal (2001).

Em resumo, as evidências empíricas para o Brasil indicam que o endividamento apresenta uma relação negativa com os fatores rentabilidade (prevista pela pecking order), crescimento (prevista pela trade-off) e tamanho. Além destes, fatores como classificação da indústria e singularidade não se mostraram significativos.

\section{Dados}

A amostra é composta por informações anuais de 110 companhias brasileiras não-financeiras ${ }^{7}$ de capital aberto observadas entre 1995 e 2001. Os dados utilizados foram extraídos dos demonstrativos contábeis consolidados e dos valores de mercado do final de cada exercício social, disponíveis na Economática. Para a obtenção dos dados referentes à variável controle acionário foram efetuadas pesquisas adicionais em periódicos como Exame - Melhores e Maiores, Gazeta Mercantil Balanço Anual e sites das empresas.

O conjunto de 110 empresas é pequeno se comparado com os utilizados em estudos americanos, mas é o que se encontra disponível para o Brasil. Na verdade, este reduzido número de companhias abertas corrobora a previsão de La Porta et alii (1997) que o uso do financiamento externo à firma (external finance) tende a ser pouco difundido sob fraca garantia legal. Ser uma amostra viesada para grandes empresas brasileiras não é um problema. Pelo contrário, na medida em que são estes os negócios com escala para cogitar todas as formas de financiamento.

As empresas foram classificadas em três categorias: privado nacional, público

\footnotetext{
${ }^{6}$ Comumente, mede-se a concentração de direitos de voto como o percentual das ações com direito a voto em poder dos acionistas controladores; e a concentração de direitos de fluxo de caixa como a parcela do capital social pertencente aos acionistas controladores.

${ }^{7} \mathrm{~A}$ exclusão das empresas financeiras deve-se ao fato das mesmas possuírem uma estrutura de capital particular.
} 
nacional ou com participação estrangeira significativa, sendo nesta última consideradas as empresas com mais de $10 \%$ de participação estrangeira na composição acionária indireta. ${ }^{8}$ Pela lei brasileira das sociedades anônimas (Lei 6404/76), o acionista com participação acima desse percentual adquire direito de voto para o conselho fiscal da empresa. Critérios alternativos como $50 \%$ e $30 \%$ de participação estrangeira, ou possuir ADR de nível maior ou igual a 2 implicam os mesmos resultados qualitativos.

As medidas de alavancagem utilizadas encontram-se descritas na tabela 3. A dívida total é desagregada em dívida de longo prazo e de curto prazo, todas como proporção do valor da firma que é mensurado pelo valor contábil e pelo valor de mercado. Além dessas, computa-se também a razão entre a dívida de longo prazo e a dívida total que permite observar a duração do endividamento para empresa.

As proxies para os fatores estudados encontram-se descritas na tabela 4 e, em geral, coincidem com as utilizadas por estudos anteriores. A escolha do coeficiente de variação do EBITDA ${ }^{9}$ como proxy para o risco é intuitiva. Dada a necessidade de lucros operacionais para honrar os serviços da dívida, uma grande volatilidade desses torna mais provável o estado de inadimplência. Alguma variável de tamanho também seria uma alternativa válida dada a sua forte relação com medidas de risco.

\footnotetext{
${ }^{8}$ Por exemplo, uma companhia que tenha $10 \%$ de suas ações em poder de outra empresa cujo controlador seja estrangeiro é considerada "com participação estrangeira".

${ }^{9} \mathrm{EBITDA}=$ Lucro Operacional antes de Juros, Impostos, Depreciação e Amortização. 
Tabela 3

Medidas de endividamento

\begin{tabular}{|c|c|}
\hline Dívida & Fórmula \\
\hline \multicolumn{2}{|l|}{ Valor Contábil } \\
\hline \multicolumn{2}{|c|}{ Total $=\frac{\text { Exigível Longo Prazo }+ \text { Passivo Circulante }}{\text { Ativo Total }}$} \\
\hline \multicolumn{2}{|r|}{ Longo Prazo $=\frac{\text { Exigível Longo Prazo }}{\text { Ativo Total }}$} \\
\hline \multicolumn{2}{|r|}{ Curto Prazo $=\frac{\text { Passivo Circulante }}{\text { Ativo Total }}$} \\
\hline \multicolumn{2}{|c|}{ Valor de Mercado } \\
\hline Total $=\overline{\text { Ati }}$ & $\begin{array}{l}\text { Exigível Longo Prazo + Passivo Circulante } \\
\text { ivo Total - Patr. Líquido + Valor Mercado Ações }\end{array}$ \\
\hline Longo Prazo $=$ & $\frac{\text { Exigível Longo Prazo }}{\text { Ativo Total - Patr. Líquido + Valor Mercado Ações }}$ \\
\hline Curto Prazo $=$ & $\frac{\text { Passivo Circulante }}{\text { Ativo Total - Patr. Líquido + Valor Mercado Ações }}$ \\
\hline$\frac{\text { Longo }}{\text { Total }}=$ & $=\frac{\text { Exigível Longo Prazo }}{\text { Exigível Longo Prazo }+ \text { Passivo Circulante }}$ \\
\hline
\end{tabular}


Tabela 4

Proxies para os fatores analisados

\begin{tabular}{|c|c|c|}
\hline Fator & Fórmula & Referência \\
\hline Priv. Nac. $=$ & $\begin{array}{l}1 \text { se menos de } 10 \% \text { de participação acionária estrangeira } \\
0 \text { caso contrário }\end{array}$ & Jorge \& Armada \\
\hline Público = & $\begin{array}{l}1 \text { para empresa de controle público nacional } \\
0 \text { caso contrário }\end{array}$ & Jorge \& Armada \\
\hline Tangibilidade $=$ & $\frac{\text { Imobilizado }+ \text { Estoques }}{\text { Ativo Total }}$ & $\begin{array}{l}\text { Titman \& Wessels e } \\
\text { Perobelli \& Famá }\end{array}$ \\
\hline Rentabilidade $=$ & $\frac{\text { EBITDA }}{\text { Ativo Total }}$ & $\begin{array}{l}\text { Rajan \& Zingales, } \\
\text { Gomes \& Leal e } \\
\text { Perobelli \& Famá }\end{array}$ \\
\hline Crescimento $=$ & $\frac{\text { Ativo Total - Patr. Líquido + Valor Mercado Ações }}{\text { Ativo Total }}$ & $\begin{array}{l}\text { Rajan \& Zingales e } \\
\text { Gomes \& Leal }\end{array}$ \\
\hline Risco $=$ & $\frac{\text { Desvio-Padrão (EBITDA) }}{\text { Médio (EBITDA) }}$ & \\
\hline
\end{tabular}

\section{Metodologia de Análise}

A análise empírica é efetuada por dois procedimentos. Primeiro comparam-se as médias de endividamento das três classes de controlador, ano a ano e de todo o período. Em seguida, efetuam-se regressões múltiplas das empresas ao longo dos anos (pooled time series and cross-section) onde se incluem outros fatores de interesse além do controlador.

Quando as regressões seccionais são empregadas, o problema de correlação dos resíduos entre as empresas é ignorado. A correlação seccional é uma característica comum aos modelos de fatores determinantes da estrutura de capital, como reportado em Fama e French (2002), Rajan e Zingales (1995), ou Cochrane (2001), sendo causada pelo desvio do conjunto das empresas da relação de longo prazo por motivos como ciclos de negócios, ciclos de crédito ou um choque macroeconômico. Os artigos que usam regressões de painel simples (pooled estimator) ignoram, além do problema de correlação seccional, o problema de viés dos erros-padrão dos coeficientes estimados devido à correlação ao longo dos anos das medidas seccionais. Tal correlação costuma ser significativa em dados de finanças corporativas por motivos como ajustamento lento para a relação de longo prazo.

Embora a correção da correlação seccional pela inclusão de dummies anuais, ou a correção da correlação serial pela estimação de resíduos auto-regressivos seja 
padrão na literatura de painel, a correção simultânea da correlação seccional das firmas e da autocorrelação das medidas anuais não é trivial.

Neste artigo efetuam-se ajustes para correlação seccional e autocorrelação, como proposto em Fama e French (2002). Pelo método de Fama e Macbeth (1973), ao invés de se calcular uma regressão seccional das médias temporais, utiliza-se uma regressão seccional para cada ano sob análise:

$$
y_{i t}=x_{i t}^{\prime} \lambda_{t}+\epsilon_{i t} \quad \forall i \quad \text { e para cada ano } t
$$

onde $y_{i t}$ é a alavancagem da empresa $i$ na data $t$;

$x_{i t}$ é um vetor com os valores dos fatores para a empresa $i$ na data $t$;

$\lambda_{t}$ é o vetor de sensibilidades seccionais da data $t$; e

$\epsilon_{i t}$ é o termo de erro para a empresa $i$ na data $t$.

Então, das estimativas seccionais $\hat{\lambda}_{t}$ para cada $t$, calcula-se um vetor de sensibilidade média:

$$
\hat{\lambda}=\frac{1}{T} \sum_{t=1}^{T} \hat{\lambda}_{t}
$$

e, dos desvios das estimativas seccionais computam-se as variâncias de $\hat{\lambda}$ :

$$
\sigma^{2}(\hat{\lambda})=\frac{1}{T^{2}} \sum_{t=1}^{T}\left(\hat{\lambda_{t}}-\hat{\lambda}\right)^{2}
$$

que estão divididas por $T^{2}$ porque são variâncias de médias amostrais. ${ }^{10} \mathrm{~A}$ vantagem desta abordagem é que as variações anuais dos coeficientes estimados, utilizadas para calcular os erros-padrão dos coeficientes médios, incluem erros de estimativa devidos à correlação seccional das firmas.

Apesar da extensão natural de Fama e MacBeth para $\hat{\lambda}_{t} \mathrm{~s}$ auto-correlacionados ser substituir a fórmula acima pela matriz de variância de longo prazo, $\sigma^{2}(\hat{\lambda})=$ $T^{-1} \sum_{t=-\infty}^{\infty} \operatorname{cov}_{T}\left(\hat{\lambda}_{t}-\hat{\lambda}_{t-j}\right)$, adota-se outro procedimento. Diante da limitação de dados para uma estimação precisa do coeficiente de autocorrelação, Fama e French (2002) calculam um fator de correção do valor crítico. Sob a hipótese de $\lambda_{t}$ ser um $A R(1)$, com variância $\sigma^{2}(\lambda)$ e autocorrelação $\rho$, a variância da soma da seqüência de $T$ observações é igual a:

\footnotetext{
${ }^{10}$ Ver Cochrane (2001) para uma comparação dos procedimentos de Fama \& MacBeth, seccional e painel.
}

RBE Rio de Janeiro 59(2):177-208 ABR/JUN 2005 


$$
\sigma^{2}\left(\sum_{t=1}^{T} \lambda_{t}\right)=T \sigma^{2}(\lambda)+2 \sigma^{2}(\lambda) \sum_{t=1}^{T-1} \sum_{j=t+1}^{T} \rho^{j-t}
$$

que para um $T$ grande, pode ser aproximada por:

$$
\sigma^{2}\left(\sum_{t=1}^{T} \lambda_{t}\right) \cong T \sigma^{2}(\lambda)+2 \sigma^{2}(\lambda) T \frac{\rho}{1-\rho}
$$

e assumindo $\rho=0.6,{ }^{11}$ tem-se $\sigma^{2}\left(\sum_{t=1}^{T} \lambda_{t}\right) \cong 4 T \sigma^{2}(\lambda)$, ou $\sigma(\hat{\lambda})=2 \sigma(\bar{\lambda})$, onde $\bar{\lambda}$ é a média de $\lambda_{t} \mathrm{~s}$ não-correlacionados. Em suma, os valores críticos devem ser multiplicados por $2 .^{12}$

\section{Resultados}

A tabela 5 apresenta, para cada ano e para todo o período, as médias do endividamento de curto prazo, longo prazo e total em termos contábeis para as três origens de controle acionário. Observa-se que as dívidas de curto prazo das empresas privadas nacionais são maiores que as das demais empresas em todos os anos, sendo significativamente maior para todo o período da amostra. Isso fornece evidência para a hipótese de que empresas nacionais enfatizam o endividamento do curto prazo. Os valores pontuais da dívida de longo prazo também indicam uso mais intenso pelas companhias privadas nacionais, embora a diferença seja não-significativa. De qualquer forma, o endividamento de longo prazo não reverte a diferença significativa da dívida de curto prazo e resta a conclusão que as firmas privadas nacionais se alavancam mais em termos contábeis.

A tabela 6 reapresenta as informações da tabela 5 em termos de valor de mercado. Observa-se um crescimento geral das medidas de endividamento, sem alterar o resultado qualitativo de maior alavancagem de curto prazo das empresas privadas nacionais.

\footnotetext{
${ }^{11}$ Segundo Fama e French (2002, p. 20), as autocorrelações de primeira ordem dos coeficientes em regressões de alavancagem variam entre 0.4 e 0.7 . Eles assumem $\rho=0.6$, que consideram uma postura conservadora.

${ }^{12}$ Por exemplo, para o nível de significância da 5\%, o valor crítico de aproximadamente 4 deve ser utilizado ao invés de aproximadamente 2 .
} 
Tabela 5

Dívida sobre o valor contábil dos ativos segundo o controle acionário

\begin{tabular}{|c|c|c|c|c|c|c|}
\hline \multirow[t]{2}{*}{ Ano } & \multirow[t]{2}{*}{ Priv. Nac. } & \multirow[t]{2}{*}{ Públic. } & \multirow[t]{2}{*}{ Estrang. } & \multicolumn{3}{|c|}{ p-valor para igualdade de médias } \\
\hline & & & & Priv. x Públic. & Priv. x Estr. & Públic. x Estr. \\
\hline \multicolumn{7}{|c|}{ Dívida de Curto Prazo } \\
\hline 1995 & 0,32 & 0,15 & 0,23 & 0,01 & 0,07 & 0,01 \\
\hline 1996 & 0,35 & 0,18 & 0,26 & 0,01 & 0,06 & 0,04 \\
\hline 1997 & 0,38 & 0,19 & 0,29 & 0,04 & 0,12 & 0,04 \\
\hline 1998 & 0,39 & 0,19 & 0,31 & 0,07 & 0,23 & 0,02 \\
\hline 1999 & 0,38 & 0,22 & 0,29 & 0,15 & 0,13 & 0,13 \\
\hline 2000 & 0,39 & 0,22 & 0,29 & 0,16 & 0,09 & 0,22 \\
\hline 2001 & 0,42 & 0,22 & 0,30 & 0,18 & 0,13 & 0,13 \\
\hline $1995-2001$ & 0,38 & 0,19 & 0,28 & $6 \mathrm{E}-07$ & $5 \mathrm{E}-05$ & $5 \mathrm{E}-08$ \\
\hline \multicolumn{7}{|c|}{ Dívida de Longo Prazo } \\
\hline 1995 & 0,14 & 0,18 & 0,15 & 0,35 & 0,63 & 0,55 \\
\hline 1996 & 0,21 & 0,19 & 0,18 & 0,72 & 0,51 & 0,82 \\
\hline 1997 & 0,24 & 0,19 & 0,19 & 0,42 & 0,24 & 1,00 \\
\hline 1998 & 0,27 & 0,16 & 0,20 & 0,16 & 0,12 & 0,37 \\
\hline 1999 & 0,35 & 0,25 & 0,23 & 0,61 & 0,20 & 0,71 \\
\hline 2000 & 0,30 & 0,26 & 0,24 & 0,76 & 0,39 & 0,77 \\
\hline 2001 & 0,35 & 0,31 & 0,25 & 0,87 & 0,31 & 0,33 \\
\hline $1995-2001$ & 0,27 & 0,21 & 0,21 & 0,20 & 0,03 & 0,91 \\
\hline \multicolumn{7}{|c|}{ Dívida Total } \\
\hline 1995 & 0,46 & 0,33 & 0,39 & 0,11 & 0,23 & 0,33 \\
\hline 1996 & 0,57 & 0,37 & 0,44 & 0,04 & 0,07 & 0,20 \\
\hline 1997 & 0,62 & 0,38 & 0,48 & 0,04 & 0,07 & 0,10 \\
\hline 1998 & 0,66 & 0,35 & 0,51 & 0,03 & 0,08 & 0,01 \\
\hline 1999 & 0,73 & 0,47 & 0,52 & 0,30 & 0,10 & 0,45 \\
\hline 2000 & 0,69 & 0,48 & 0,53 & 0,39 & 0,18 & 0,51 \\
\hline 2001 & 0,76 & 0,53 & 0,55 & 0,47 & 0,19 & 0,84 \\
\hline $1995-2001$ & 0,64 & 0,40 & 0,49 & $4 \mathrm{E}-04$ & $3 \mathrm{E}-04$ & $2 \mathrm{E}-04$ \\
\hline
\end{tabular}

Notas: (i) Dívidas de curto prazo, longo prazo e total computadas como descrito na seção

5. (ii) Os tamanhos das classes privadas nacionais, públicas e estrangeiras variam durante o período, sendo respectivamente iguais: a 80, 11 e 19 em 1995 e 1996; a 79, 10 e 21 em 1997; a 79, 8 e 23 em 1998; a 79, 6 e 25 em 1999 e 2000; a 80, 6 e 24 em 2001; e a 556, 58 e 156 em 1995-2001. (iii) p-valores reportados para o teste $\mathrm{F}$ com $\mathrm{H}_{0}$ : as duas classes têm a mesma média.

É importante lembrar que uma pecking order mais forte para as firmas de controle privado nacional não implica uma menor alavancagem de curto prazo ou mesmo uma menor alavancagem total. Afinal, o endividamento de curto prazo é a primeira alternativa ao esgotamento dos recursos internos e, embora mais caro para as empresas de pior governança, é relativamente mais barato que dívida de longo prazo ou emissão do novas ações, ambos mais sensíveis aos riscos de agência. Este menor custo da dívida de curto prazo relativamente às outras formas de financiamento externo, e também da dívida de longo prazo relativamente à emissão de ações, deve motivar um uso mais intenso de dívida relativamente à emissão de 
ações, e pode ser suficiente importante para causar uma maior alavancagem das empresas de controle privado nacional.

Tabela 6

Dívida sobre o valor de mercado dos ativos segundo o controle acionário

\begin{tabular}{|c|c|c|c|c|c|c|}
\hline \multirow[t]{2}{*}{ Ano } & \multirow{2}{*}{ Priv. Nac. } & \multirow{2}{*}{ Públic. } & \multirow{2}{*}{ Estrang. } & \multicolumn{3}{|c|}{ p-valor para igualdade de médias } \\
\hline & & & & Priv. x Públic. & Priv. x Estr. & Públic. x Estr. \\
\hline \multicolumn{7}{|c|}{ Dívida de Curto Prazo } \\
\hline 1995 & 0,46 & 0,22 & 0,36 & 0,00 & 0,06 & 0,01 \\
\hline 1996 & 0,45 & 0,21 & 0,36 & 0,00 & 0,08 & 0,00 \\
\hline 1997 & 0,46 & 0,20 & 0,40 & 0,00 & 0,18 & 0,01 \\
\hline 1998 & 0,46 & 0,30 & 0,45 & 0,03 & 0,84 & 0,01 \\
\hline 1999 & 0,38 & 0,23 & 0,33 & 0,04 & 0,16 & 0,10 \\
\hline 2000 & 0,40 & 0,27 & 0,34 & 0,08 & 0,13 & 0,25 \\
\hline 2001 & 0,41 & 0,25 & 0,35 & 0,03 & 0,14 & 0,08 \\
\hline $1995-2001$ & 0,43 & 0,24 & 0,37 & $2 \mathrm{E}-13$ & $2 \mathrm{E}-04$ & $3 \mathrm{E}-10$ \\
\hline \multicolumn{7}{|c|}{ Dívida de Longo Prazo } \\
\hline 1995 & 0,20 & 0,27 & 0,24 & 0,19 & 0,32 & 0,58 \\
\hline 1996 & 0,26 & 0,22 & 0,27 & 0,50 & 0,78 & 0,35 \\
\hline 1997 & 0,29 & 0,20 & 0,28 & 0,14 & 0,77 & 0,11 \\
\hline 1998 & 0,32 & 0,28 & 0,31 & 0,58 & 0,73 & 0,69 \\
\hline 1999 & 0,30 & 0,34 & 0,26 & 0,65 & 0,45 & 0,34 \\
\hline 2000 & 0,29 & 0,36 & 0,28 & 0,38 & 0,96 & 0,33 \\
\hline 2001 & 0,30 & 0,42 & 0,29 & 0,19 & 0,86 & 0,14 \\
\hline $1995-2001$ & 0,28 & 0,28 & 0,28 & 0,95 & 0,91 & 0,88 \\
\hline \multicolumn{7}{|c|}{ Dívida Total } \\
\hline 1995 & 0,66 & 0,48 & 0,60 & 0,03 & 0,32 & 0,14 \\
\hline 1996 & 0,71 & 0,43 & 0,63 & 0,00 & 0,15 & 0,01 \\
\hline 1997 & 0,75 & 0,40 & 0,67 & 0,00 & 0,11 & 0,00 \\
\hline 1998 & 0,78 & 0,59 & 0,76 & 0,00 & 0,55 & 0,01 \\
\hline 1999 & 0,67 & 0,57 & 0,59 & 0,28 & 0,09 & 0,85 \\
\hline 2000 & 0,69 & 0,63 & 0,62 & 0,56 & 0,20 & 0,92 \\
\hline 2001 & 0,71 & 0,67 & 0,65 & 0,66 & 0,18 & 0,77 \\
\hline $1995-2001$ & 0,71 & 0,52 & 0,65 & $8 \mathrm{E}-11$ & $8 \mathrm{E}-04$ & $2 \mathrm{E}-05$ \\
\hline \multicolumn{7}{|c|}{$\begin{array}{l}\text { Notas: (i) Dívidas de curto prazo, longo prazo e total computadas como descrito na seção } \\
\text { 5. (ii) Os tamanhos das classes privadas nacionais, públicas e estrangeiras variam durante o } \\
\text { período, sendo respectivamente iguais: a } 80,11 \text { e } 19 \text { em } 1995 \text { e } 1996 \text {; a } 79,10 \text { e } 21 \text { em } 1997 \text {; } \\
\text { a } 79,8 \text { e } 23 \text { em } 1998 \text {; a } 79,6 \text { e } 25 \text { em } 1999 \text { e } 2000 ; \text { a } 80,6 \text { e } 24 \text { em } 2001 \text {; e a } 556,58 \text { e } 156 \text { em } \\
1995-2001 \text {. (iii) p-valores reportados para o teste } \mathrm{F} \text { com } \mathrm{H}_{0} \text { : as duas classes têm a mesma } \\
\text { média. }\end{array}$} \\
\hline
\end{tabular}

Os resultados das tabelas 5 e 6 sugerem o cálculo de alguma medida de duração do endividamento das empresas. Com tal finalidade, a tabela 7 calcula a razão dívida de longo prazo sobre dívida total. Observa-se que a duração da dívida das empresas públicas é significativamente maior, em acordo com Smith Jr. (1986), segundo o qual os empréstimos longos geram menos problemas de agência para essas. Tem-se ainda uma evidência fraca que as firmas com participação estrangeira possuem duração maior que as privadas nacionais. 
Tabela 7

Razão dív.longo prazo/dív.total segundo o controle acionário

\begin{tabular}{ccccccc}
\hline Ano & Priv. Nac. & Públic. & Estrang. & \multicolumn{2}{c}{ p-valor para igualdade de médias } \\
\cline { 4 - 6 } & & & & Priv. x Públic. & Priv. x Estr. & Públic. x Estr. \\
\hline 1995 & 0,28 & 0,54 & 0,38 & 0,00 & 0,04 & 0,03 \\
1996 & 0,36 & 0,51 & 0,41 & 0,04 & 0,38 & 0,13 \\
1997 & 0,38 & 0,50 & 0,41 & 0,11 & 0,55 & 0,17 \\
1998 & 0,40 & 0,46 & 0,40 & 0,53 & 0,90 & 0,45 \\
1999 & 0,41 & 0,57 & 0,41 & 0,09 & 0,90 & 0,09 \\
2000 & 0,40 & 0,56 & 0,43 & 0,08 & 0,44 & 0,17 \\
2001 & 0,41 & 0,61 & 0,43 & 0,03 & 0,69 & 0,06 \\
$1995-2001$ & 0,38 & 0,53 & 0,41 & 1 E-06 & 0,07 & 5 E- 05 \\
\hline Notas: (i) Razão dívida de longo prazo sobre dívida total computada como descrito na seção 5; (ii) \\
Os tamanhos das classes privadas nacionais, públicas e estrangeiras variam durante o período, sendo \\
respectivamente iguais a 80, 11 e 19 em 1995 e 1996; a 79, 10 e 21 em 1997; a 79, 8 e 23 em 1998; \\
a 79, 6 e 25 em 1999 e 2000; a 80, 6 e 24 em 2001; e a 556, 58 e 156 em 1995-2001; (iii) p-valores \\
reportados para o teste F com $H_{0}$ : as duas classes têm mesma média.
\end{tabular}

Embora os resultados das tabelas 5, 6 e 7 indiquem empresas privadas nacionais mais alavancadas e com duração inferior, não são evidências necessárias nem suficientes que a decisão de alavancagem se deveu à origem dos controladores. Muito menos permitem distinguir se estas diferenças são devidas às empresas estrangeiras possuírem empréstimos internacionais de prazos maiores (Barclay e Smith Jr., 1995), ou se são devidas à diferença de qualidade da governança corporativa cogitada neste artigo, dada a ausência de outras variáveis de controle na análise.

Em busca de uma evidência mais forte da relação entre endividamento e origem do controlador, efetuam-se regressões múltiplas do tipo:

$$
\begin{aligned}
\text { Dívida }_{t} & =\alpha+\lambda_{1} \text { Priv.Nac. }_{t}+\lambda_{2} \text { Público }_{t}+\lambda_{3} \text { Tangibilidade }_{t} \\
& +\lambda_{4} \text { Rentabilidade }_{t}+\lambda_{5} \text { Crescimento }_{t}+\lambda_{4} \text { Risco }_{t}+\epsilon_{t}
\end{aligned}
$$

onde Dívida é uma das medidas de endividamento descritas na tabela 3, e Priv. Nac., Público, Tangibilidade, Rentabilidade, Crescimento e Risco são os fatores considerados, construídos como indicado na tabela 4. Por simplicidade, omitem-se o subscrito da firma, que deveria aparecer nas variáveis e no resíduo, e o subscrito temporal, que deveria aparecer nos coeficientes.

Como verificado em Rajan e Zingales (1995) e Gomes e Leal (2001) entre outros, a tabela 8 mostra o fator tangibilidade positivamente relacionado ao endividamento total e de longo prazo, confirmando a hipótese que colaterais tangíveis reduzem os custos de insolvência. Enquanto isso, uma fraca relação negativa desse 
fator com o endividamento de curto prazo indica que empresas com maior proporção de ativos tangíveis utilizam menos financiamento de curto prazo.

Tabela 8

Estimativas da regressão (1) dos determinantes do endividamento

\begin{tabular}{|c|c|c|c|c|c|c|c|}
\hline & \multicolumn{3}{|c|}{$\begin{array}{l}\text { sobre o ativo total } \\
\text { em valor contábil }\end{array}$} & \multicolumn{4}{|c|}{$\begin{array}{l}\text { sobre o ativo total } \\
\text { em valor de mercado }\end{array}$} \\
\hline & Total 1 & Longo Prazo & Curto Prazo & Total & Longo Prazc & Curto Prazo & Longo/Total \\
\hline \multirow[t]{2}{*}{ Privado } & 0,060 & 0,024 & 0,035 & 0,023 & $-0,001$ & 0,024 & $-0,018$ \\
\hline & 5,75 & 2,58 & 3,59 & 3,12 & $-0,15$ & 1,96 & $-1,47$ \\
\hline \multirow[t]{2}{*}{ Público } & $-0,102$ & $-0,016$ & $-0,086$ & $-0,159$ & $-0,019$ & $-0,141$ & 0,091 \\
\hline & $-3,02$ & $-0,66$ & $-5,23$ & $-4,38$ & $-0,63$ & $-12,31$ & 4,41 \\
\hline \multirow[t]{2}{*}{ Tangibilidade } & 0,221 & 0,312 & $-0,091$ & 0,214 & 0,334 & $-0,120$ & 0,385 \\
\hline & 6,36 & 12,18 & $-2,96$ & 5,68 & 16,93 & $-2,45$ & 24,07 \\
\hline \multirow[t]{2}{*}{ Rentabilidade } & $-1,389$ & $-0,787$ & $-0,602$ & $-1,182$ & $-0,641$ & $-0,540$ & $-0,372$ \\
\hline & $-8,44$ & $-4,35$ & $-7,06$ & $-16,39$ & $-9,41$ & $-5,85$ & $-5,24$ \\
\hline \multirow[t]{2}{*}{ Crescimento } & 0,688 & 0,317 & 0,370 & $-0,004$ & 0,013 & $-0,016$ & 0,026 \\
\hline & 16,97 & 7,15 & 10,80 & $-0,17$ & 1,07 & $-0,76$ & 2,33 \\
\hline \multirow[t]{2}{*}{ Risco } & $-0,003$ & $-0,004$ & 0,001 & $-0,002$ & $-0,005$ & 0,003 & $-0,006$ \\
\hline & $-2,53$ & $-4,03$ & 5,07 & $-1,89$ & $-5,39$ & 6,15 & $-7,13$ \\
\hline$\overline{\text { Pseudo } \mathrm{R}^{2}}$ & $68 \%$ & $48 \%$ & $52 \%$ & $31 \%$ & $20 \%$ & $23 \%$ & $19 \%$ \\
\hline
\end{tabular}

Notas: (i) Reportam-se as médias temporais das sensibilidades seccionais e suas estatísticas $t$, computadas como descrito na seção 6. (ii) O intercepto foi omitido. (iii) A amostra é composta por 110 empresas abertas durante o período 1995-2001. (iv) As variáveis utilizadas estão descritas na seção 5. (v) Pseudo $R^{2}$ é a média temporal dos $R^{2}$ seccionais

Identifica-se uma relação negativa entre rentabilidade e endividamento das empresas, conforme verificado por Gomes e Leal (2001) ou Perobelli e Famá (2002) para o Brasil e por Titman e Wessels (1988) ou Rajan e Zingales (1995) para outros países. A relação negativa pode ser justificada pela teoria de pecking order, onde empresas mais rentáveis são menos endividadas porque têm recursos próprios em volume compatível com seus projetos de investimento. Note-se que a relação negativa entre rentabilidade e alavancagem fica mais precisa quando esta última é medida em valor de mercado.

Consistente com o modelo simples de pecking order, verifica-se uma relação positiva entre o crescimento e o endividamento contábil, devido a este último ser o resultado do acúmulo das diferenças entre investimentos e lucros retidos. Esta evidência diverge de Gomes e Leal (2001) ou Perobelli e Famá (2002). Também interessante é o fato do endividamento em valor de mercado não apresentar relação significativa com o crescimento, como advertido por Fama e French (2002) caso a pecking order valha (descrito na seção 3).

Apesar dos resultados obtidos indicarem que empresas mais arriscadas se endividam menos a longo prazo, como esperado por trade-off e pecking order, explica-se abaixo que este resultado não é robusto a pequenas variações na modelagem. Vale 
destacar que outras variáveis como desvio-padrão da rentabilidade, beta e volatilidade da ação haviam sido utilizadas anteriormente para mensurar o fator risco das empresas brasileiras sem apresentarem a significância prevista.

Finalmente, o controle acionário parece importar para a alavancagem de curto prazo e total, indicando que a origem do controlador influencia nas decisões quanto à estrutura de capital. As empresas de controle privado nacional se endividam mais que aquelas de controle público ou estrangeiro, pelo uso intensivo de dívida de curto prazo. Já as empresas públicas se endividam menos e utilizam significativamente menos dívida de curto prazo.

Os resultados da tabela 8 levantam suspeitas sobre a relevância da origem do controle na escolha da estrutura de capital, mesmo após controlar para outros fatores relevantes. Além da importância da origem do controle, indica-se que pecking order prepondera sobre trade-off, com os demais custos de falência e assimetria de informação demonstrando sua importância esperada. Tais conclusões parecem robustas ao método de estimação, como observado na tabela A.1 do apêndice, que reestima a equação (1) por painel com dummies anuais para tratar a correlação seccional dos dados. A regressão (1) também foi estimada por painel com efeito fixo e erros $A R(1)$, mas sem dummies anuais. ${ }^{13}$ Os resultados não se mostram inconsistentes com os reportados acima, embora o fator risco perca a significância.

Contudo, a evidência da tabela 8 não é suficiente para concluir pela relação entre a origem dos controladores e a reputação no resguardo dos direitos de propriedade dos financiadores externos à firma, como extrapolado de La Porta et alii (1998, 1997) na seção 2. Semelhante a Barclay e Smith Jr. (1995), é possível argumentar que as firmas com participação estrangeira têm dívida com duração maior porque têm empréstimos no exterior onde os prazos são mais longos. Ou pode-se explicar as diferenças de estrutura de capital pelo ingênuo argumento de importação cultural, segundo o qual as firmas estrangeiras impõem sua política de financiamento às associadas locais.

Se motivos como os dois últimos são a razão das diferenças de estrutura de capital, entre os grupos de controladores, não se devem observar significativas diferenças de sensibilidade aos custos de insolvência e à assimetria de informação. Ou seja, uma vez incorporadas as variáveis de origem do controle, entre os grupos não deveria haver diferenças de sensibilidade aos fatores tangibilidade, rentabilidade, crescimento e risco, dado que todas empresas estariam sujeitas aos mesmos custos de agência. Por outro lado, se a origem do controlador sinaliza a qualidade da governança, no ambiente brasileiro de fraca garantia legal, onde a boa governança privada ganha relevância, significativas diferenças de sensibilidade aos custos de

\footnotetext{
${ }^{13}$ Por concisão, não são apresentadas no artigo, mas podem ser solicitadas.
} 
insolvência e à assimetria de informação devem ser observadas. Ou seja, deve haver diferenças de sensibilidade aos fatores tangibilidade, rentabilidade, crescimento e risco entre os grupos de controladores.

Para avançar na exploração desta hipótese, é interessante incluir termos de interação do controle nacional privado com as outras variáveis independentes para permitir que as sensibilidades variem entre as empresas como função da origem do controlador:

$$
\begin{aligned}
& \text { Divida }_{t}=\alpha+\lambda_{1} \text { Priv.Nac.t }+\lambda_{2} \text { Público }_{t} \\
&+\left(\lambda_{31}+\lambda_{32} \text { Priv.Nac.t }\right) \text { Tangibilidade }_{t} \\
&+\left(\lambda_{41}+\lambda_{42} \text { Priv.Nac. }_{t}\right) \text { Rentabilidade } \\
& \\
&+\left(\lambda_{51}+\lambda_{52} \text { Priv.Nac. }_{t}\right) \text { Crescimento }_{t} \\
&+\left(\lambda_{61}+\lambda_{62} \text { Priv.Nac. }_{t}\right) \text { Risco }_{t}+\epsilon_{t}
\end{aligned}
$$

Se o controle nacional privado é proxy para o grupo de pior governança, esperase um maior custo de agência para este grupo, refletido em termos de interação que reforçam as sensibilidades obtidas na tabela 8. Ainda, se participação estrangeira reúne o grupo de melhor governança, os termos simples (dos demais fatores) devem perder significância e podem mesmo mudar de sinal, indicando menores custos relativos de insolvência e assimetria de informação. Como o foco do trabalho é a pior governança das empresas privadas nacionais, assume-se para as públicas os mesmos coeficientes que para as estrangeiras. Além de parcimoniosa, esta separação é conservadora, pois, se as empresas públicas tiverem pior governança que as estrangeiras, as sensibilidades comuns ficarão aumentadas e será mais difícil comprovar uma diferença significativa entre as firmas privadas nacionais e as demais.

A tabela 9, que reporta as estimativas da regressão (2), apresenta estimativas coerentes com a hipótese de relação significativa entre participação estrangeira e melhor governança. Em geral, os termos simples dos fatores tradicionais diminuem em módulo e em significância, enquanto os termos de interação mantêm o sinal anterior e a significância. Ou seja, a evidência da tabela 9 é que a diferença de estrutura de capital não se deve simplesmente à origem dos controladores, mas aos maiores custos relativos de insolvência e assimetria de informação das firmas privadas nacionais. 
Tabela 9

Estimativas da regressão (2) dos determinantes do endividamento

\begin{tabular}{lccccccc}
\hline & \multicolumn{3}{c}{ sobre o ativo total } & \multicolumn{4}{c}{ sobre o ativo total } \\
& \multicolumn{3}{c}{ em valor contábil } \\
\cline { 2 - 8 } Total Longo Prazo Curto Prazo Total Longo Prazo Curto Prazo Longo/Total
\end{tabular}

Notas: (i) Reportam-se as médias temporais das sensibilidades seccionais e suas estatísticas $t$, computadas como descrito na seção 6. (ii) $\mathrm{O}$ intercepto foi omitido. (iii) $\mathrm{A}$ amostra é composta por 110 empresas abertas durante o período 1995-2001. (iv) As variáveis utilizadas estão descritas na seção 5. (v) Priv.Total é a média temporal de $\lambda_{1}+\lambda_{32}$ $\mathrm{M}($ A.Tangíveis $t)+\lambda_{42} \mathrm{M}\left(\right.$ Rentabilidade $\left._{t}\right)+\lambda_{52} \mathrm{M}($ Crescimento $)+\lambda_{62} \mathrm{M}($ Risco $t$, sendo $\mathrm{M}($.$) a$ média seccional da variável. (vi) Pseudo $\mathrm{R}^{2}$ é a média temporal dos $\mathrm{R}^{2}$ seccionais.

A favor do mesmo argumento, interessa notar que todos os termos simples do controle privado nacional (primeira linha da tabela 9) tornam-se negativos, exceto pela última coluna de intuição diferente. Isso indica que toda a relação positiva entre endividamento e controle privado nacional mensurada na tabela 7 era devida aos maiores custos de insolvência e assimetria de informação (aos termos de interação). Agrupando os efeitos do controle privado nacional na equação (2), recupera-se o efeito total deste, mostrado no segundo termo do lado direito da equação abaixo:

$$
\begin{aligned}
\text { Divida }_{t}= & \alpha+\left(\lambda_{1}+\lambda_{32} \text { Tangib }_{t}+\lambda_{42} \text { Rentab } \cdot t_{t}+\lambda_{52} \text { Cresc. }_{t}+\lambda_{62} \text { Risco }_{t}\right) \\
& \text { Priv.Nac. } \cdot+\lambda_{2} \cdot \text { Público }_{t}+\lambda_{31} \text { Tangibilidade }_{t}+\lambda_{41} \text { Rentabilidade }_{t} \\
+ & \lambda_{51} \text { Crescimento }_{t}+\lambda_{61} \text { Risco }_{t}+\epsilon_{t}
\end{aligned}
$$


Na última linha da tabela 9 lêem-se os efeitos totais médios do controle privado nacional. Como previsto, observa-se que estas firmas fazem uso intensivo de dívida de curto prazo. Os resultados da tabela 9 também parecem robustos ao método de estimação, como observado na tabela A.2 do apêndice, que reestima a equação (2) utilizando técnicas de Painel.

\section{Considerações Finais}

Estudando o impacto simultâneo do controle acionário, tangibilidade, crescimento, rentabilidade e risco para o período entre 1995 e 2001, mostrou-se que as empresas de controle privado nacional se endividam mais que as de controle público nacional ou de controle estrangeiro, e que isso é conseguido pelo uso intensivo de dívida de curto prazo.

Mais do que uma simples diferença de estrutura de capital segundo a origem do controlador, indicou-se que esta parece devida aos maiores custos de insolvência e assimetria de informação suportados pelas firmas privadas nacionais, com pior governança num ambiente de fraca garantia legal.

Adicionalmente, a relação positiva entre o fator tangibilidade e endividamento total ou de longo prazo confirmou o previsto pela teoria de trade-off. O crescimento apresentou relação positiva com o endividamento e, conjuntamente com a relação negativa da rentabilidade, favoreceram a teoria de pecking order contra a teoria de trade-off. Ainda, como esperado por trade-off e pecking order, a volatilidade se mostrou negativamente relacionada à dívida de longo prazo. 


\section{Referências}

Barclay, J. \& Smith Jr., C. (1995). The maturity structure of corporate debt. Journal of Finance, 50:609-631.

Carvalhal Da Silva, A. (2002). A influência da estrutura de controle e propriedade no valor, estrutura de capital e política de dividendos dos empresas brasileiras. Tese Doutorado em Administração - Instituto COPPEAD de Administração Universidade Federal do Rio de Janeiro.

Cochrane, J. (2001). Asset Pricing. Princeton University Press, NJ.

DeAngelo, H. \& Masulis, R. (1980). Optimal capital structure under corporate and personal taxation. Journal of Financial Economics, 8:3-29.

Eid Jr., W. (1996). Custo e estrutura de capital: O comportamento das empresas brasileiras. Revista de Administração de Empresas, 36(4):51-59.

Fama, E. \& French, K. (2002). Testing trade-off and pecking order predictions about dividends and debt. The Review of Financial Studies, 15(1):1-33.

Fama, E. \& Macbeth, J. (1973). Risk, return, and equilibrium: Empirical tests. Journal of Political Economy, 81:607-636.

Flannery, M. (1986). Asymmetric information and risky debt maturity choice. Journal of Finance, 41:19-37.

Gomes, G. \& Leal, R. (2001). Determinantes da estrutura de capitais das empresas brasileiras com ações negociadas em bolsas de valores. In Leal, R. and Costa Jr., N., \& Lemgruber, E. (editores), Finanças Corporativas. Atlas, São Paulo.

Harris, M. \& Raviv, A. (1991). The theory of capital structure. The Journal of Finance, 46(1):297-355.

Hart, O. (1995). Firms, Contracts and Financial Structure. Oxford Press, London.

Jensen, M. (1986). Agency costs of free-cash-flow, corporate finance, and takeovers. American Economic Review, 76:323-329.

Jensen, M. \& Meckling, W. (1976). Theory of the firm: Managerial behavior, agency costs and ownership structure. Journal of Financial Economics, 3:305360.

RBE Rio de Janeiro 59(2):177-208 ABR/JUN 2005 
Jorge, S. \& Armada, M. (2001). Factores determinantes do endividamento: Uma análise em painel. Revista de Administração Contemporânea, 5(2):9-31.

Kayo, E. \& Famá, R. (1997). Teoria de agência e crescimento: Evidências empíricas dos efeitos positivos e negativos do endividamento. Caderno de Pesquisas em Administração, 2(5):1-8.

La Porta, R., Lopez-de Silanes, F., Shleifer, A., \& Vishny, R. (1997). Legal determinants of external finance. Journal of Finance, 52:1131-1150.

La Porta, R., Lopez-de Silanes, F., Shleifer, A., \& Vishny, R. (1998). Law and finance. Journal of Political Economy, 106:1113-1155.

Miller, M. (1977). Debt and taxes. Journal of Finance, 32:261-275.

Modigliani, F. \& Miller, M. (1958). The cost of capital, corporation finance and the theory of investment. American Economic Review, 48:261-297.

Modigliani, F. \& Miller, M. (1963). Corporate income taxes and the cost of capital: A correction. American Economic Review, 53:433-443.

Moreira, M. \& Puga, F. (2001). Como a indústria financia o seu crescimento: Uma análise do Brasil Pós-Plano Real. Revista Econômica Contemporânea, 5:35-67.

Myers, S. (1984). The capital structure puzzle. Journal of Finance, 39:575-592.

Myers, S. \& Majluf, N. (1984). Corporate financing and investment decisions when firms have information that investors do not have. Journal of Financial Economics, 13:187-221.

Novaes, W. \& Werlang, S. (2002). Political risk and capital structure choice of foreign subsidiaries: An empirical analysis. mimeo.

Perobelli, F. \& Famá, R. (2002). Determinantes da estrutura de capital: Aplicação a empresas de capital aberto brasileiras. Revista de Administração da Universidade de São Paulo, 37.

Rajan, R. G. \& Zingales, L. (1995). What do we know about capital structure? Some evidence from international data. Journal of Finance, 50(5):1421-1460.

Reese, W. \& Weisbach, M. (2002). Protection of minority shareholder interests, cross-listing in the United States, and subsequent equity offerings. Journal of Financial Economics, 66:65-104. 
Smith Jr., C. (1986). Investment banking and the capital acquisition process. Journal of Financial Economics, 15:3-29.

Srour, G. (2002). Práticas diferenciadas de governança corporativa: Um estudo sobre a conduta e a performance das firmas brasileiras. Anais do II Encontro Brasileiro de Finanças.

Stulz, R. (1990). Managerial discretion and optimal financing policies. Journal of Financial Economics, 26:3-27.

Titman, S. \& Wessels, R. (1988). The determinants of capital structure choice. Journal of Finance, 43(1):1-19. 


\section{Anexo}

\section{Regressões de Painel com Dummies Anuais}

Tabela A.1

Estimativas da regressão (1) dos determinantes do endividamento

\begin{tabular}{lccccccc}
\hline & \multicolumn{3}{c}{$\begin{array}{c}\text { Sobre o ativo total } \\
\text { em valor contábil }\end{array}$} & \multicolumn{5}{c}{ sobre o ativo total } \\
Total & Longolor de mercado \\
\cline { 2 - 7 } Privado & 0,061 & 0,022 & 0,039 & 0,025 & $-0,001$ & 0,026 & $-0,018$ \\
& 3,14 & 1,48 & 3,12 & 1,56 & $-0,09$ & 2,15 & $-1,18$ \\
Público & $-0,115$ & $-0,019$ & $-0,096$ & $-0,175$ & $-0,026$ & $-0,149$ & 0,092 \\
& $-4,12$ & $-0,97$ & $-5,28$ & $-6,95$ & $-1,14$ & $-7,48$ & 3,22 \\
Tangibilidade & 0,187 & 0,276 & $-0,088$ & 0,202 & 0,314 & $-0,113$ & 0,370 \\
& 4,57 & 7,97 & $-2,54$ & 5,15 & 10,12 & $-2,89$ & 9,71 \\
Rentabilidade & $-1,393$ & $-0,865$ & $-0,528$ & $-1,135$ & $-0,647$ & $-0,489$ & $-0,388$ \\
& $-11,75$ & $-5,17$ & $-3,83$ & $-14,06$ & $-8,42$ & $-5,78$ & $-4,41$ \\
Crescimento & 0,723 & 0,395 & 0,328 & $-0,022$ & 0,026 & $-0,048$ & 0,046 \\
& 9,97 & 7,78 & 9,22 & $-1,08$ & 1,90 & $-3,26$ & 3,50 \\
Risco & $-0,003$ & $-0,004$ & 0,001 & $-0,003$ & $-0,005$ & 0,002 & $-0,005$ \\
& $-2,05$ & $-3,53$ & 1,10 & $-2,00$ & $-5,84$ & 2,49 & $-6,86$ \\
\hline $\mathrm{R}^{2}$ & $73 \%$ & $57 \%$ & $52 \%$ & $30 \%$ & $19 \%$ & $21 \%$ & $19 \%$ \\
\hline Notas: (i) Reportam-se as sensibilidades computadas por Painel com dummies anuais para \\
minimizar a correlação seccional; e (ii) suas estatísticas $t$ calculadas pela matriz de White. \\
(iii) O intercepto as dummies anuais foram omitidas. (iv) A amostra é composta por 110 \\
empresas abertas durante o período 1995-2001. (v) As variáveis utilizadas estão descritas na \\
seção 5.
\end{tabular}


Tabela A.2

Estimativas da regressão (2) dos determinantes do endividamento

\begin{tabular}{lccccccc}
\hline & \multicolumn{3}{c}{ sobre o ativo total } & \multicolumn{3}{c}{ sobre o ativo total } \\
& em valor contábil & \multicolumn{3}{c}{ em valor de mercado } \\
\cline { 2 - 7 } Total & Longo Prazo Curto Prazo Total Longo Prazo Curto Prazo Longo/Total \\
\hline Privado & $-0,535$ & $-0,338$ & $-0,197$ & $-0,415$ & $-0,313$ & $-0,102$ & $-0,202$ \\
Público & $-6,26$ & $-5,50$ & $-3,46$ & $-5,25$ & $-5,29$ & $-1,58$ & $-2,76$ \\
& $-0,076$ & $-0,010$ & $-0,066$ & $-0,152$ & $-0,030$ & $-0,122$ & 0,074 \\
Tangibilidade & $-3,98$ & $-0,59$ & $-4,60$ & $-6,70$ & $-1,37$ & $-6,40$ & 2,46 \\
& $-0,148$ & 0,096 & $-0,244$ & $-0,112$ & 0,120 & $-0,232$ & 0,286 \\
Tangib.*Priv. & $-2,59$ & 2,25 & $-5,76$ & $-1,54$ & 2,15 & $-4,26$ & 4,06 \\
& 0,398 & 0,205 & 0,193 & 0,389 & 0,232 & 0,157 & 0,091 \\
Rentabilidade & 5,18 & 3,42 & 3,18 & 4,51 & 3,50 & 2,17 & 1,12 \\
& $-0,485$ & $-0,665$ & 0,180 & $-0,715$ & $-0,821$ & 0,106 & $-0,859$ \\
Rentab.*Priv. & $-3,06$ & $-5,32$ & 1,71 & $-4,57$ & $-6,03$ & 0,84 & $-4,84$ \\
& $-0,887$ & $-0,118$ & $-0,770$ & $-0,436$ & 0,247 & $-0,683$ & 0,594 \\
Crescimento & $-4,55$ & $-0,55$ & $-4,09$ & $-2,47$ & 1,56 & $-4,30$ & 2,96 \\
& 0,187 & 0,113 & 0,074 & $-0,292$ & $-0,097$ & $-0,196$ & 0,009 \\
Cresc. ${ }^{*}$ Priv. & 3,89 & 3,06 & 3,06 & $-7,40$ & $-2,95$ & $-6,59$ & 0,22 \\
& 0,583 & 0,311 & 0,272 & 0,294 & 0,138 & 0,156 & 0,047 \\
Risco & 6,86 & 4,94 & 6,30 & 6,70 & 3,90 & 4,70 & 1,07 \\
& 0,062 & 0,024 & 0,038 & $-0,009$ & $-0,041$ & 0,032 & $-0,029$ \\
Risco*Priv. & 1,89 & 1,05 & 1,84 & $-0,26$ & $-1,67$ & 1,26 & $-1,01$ \\
& $-0,065$ & $-0,028$ & $-0,037$ & 0,007 & 0,036 & $-0,029$ & 0,024 \\
& $-1,96$ & $-1,20$ & $-1,79$ & 0,19 & 1,47 & $-1,17$ & 0,83 \\
\hline $\mathrm{R}^{2}$ & $76 \%$ & $60 \%$ & $54 \%$ & $34 \%$ & $22 \%$ & $23 \%$ & $20 \%$ \\
\hline Priv. Total & 0,094 & 0,024 & 0,069 & 0,030 & $-0,020$ & 0,050 & $-0,092$ \\
& 4,23 & 1,68 & 8,56 & 3,21 & $-2,67$ & 13,03 & $-13,00$ \\
\hline
\end{tabular}

Notas: (i) Reportam-se as sensibilidades computadas por Painel com dummies anuais para minimizar a correlação seccional; e (ii) suas estatísticas $t$ calculadas pela matriz de White. (iii) $\mathrm{O}$ intercepto e as dummies anuais foram omitidas. (iv) A amostra é composta por 110 empresas abertas durante o período 1995-2001. (v) As variáveis utilizadas estão descritas na seção 5. (vi) Priv.Total é a média temporal de $\lambda_{1}+$ $\lambda_{32} \mathrm{M}$ (A.Tangíveis $t+\lambda_{42} \mathrm{M}\left(\right.$ Rentabilidade $_{t}+\lambda_{52} \mathrm{M}\left(\right.$ Crescimento $\left._{t}\right)+\lambda_{62} \mathrm{M}\left(\mathrm{Risco}_{t}\right)$, sendo $\mathrm{M}($.) a média seccional da variável. 